Health Foundation, London, UK

Hugh.Alderwick@health.org.uk Cite this as: BMJ 2020;371:m4468 http://dx.doi.org/10.1136/bmj.m4468 Published: 18 November 2020

\section{NHS reorganisation after the pandemic}

\author{
Major structural change should not be part of the plan for recovery \\ Hugh Alderwick head of policy
}

Before covid-19 hit, national NHS bodies had asked the government to make changes to NHS legislation. These changes were designed to make it easier for NHS organisations in England to collaborate to plan and deliver services-including through establishing joint committees between commissioners and providers. ${ }^{2}$ Since then, government and the NHS have been focused on managing covid-19. Proposals for new legislation were temporarily shelved.

But not for long: legislation for the NHS in England seems to be back on the agenda. Media stories emerged in the summer that the prime minister was considering proposals for a major NHS

reorganisation-including changes to bring national NHS bodies under closer political control. ${ }^{3}$ NHS commentators are calling for legislation to give greater power to local leaders to reorganise care as the NHS recovers from the pandemic. ${ }^{4}$ And changes to the English public health system currently being considered by government-set in motion by the poorly timed decision to abolish Public Health England back in August-include returning some public health responsibilities to the NHS. ${ }^{5}$

The rationale for legislation depends on who you ask-and involves a mix of policy and politics. For NHS leaders, the argument is that the rules governing the NHS make it harder to deliver the improvements promised in the NHS long term plan-including better integration between health and social care and a greater focus on disease prevention.

Analysts of institutions often focus on the interaction between the "rules in form"-the formal rules that govern how systems work on paper-and the "rules in use"-the way things actually work in practice. ${ }^{6}$ The Health and Social Care Act 2012 introduced widespread changes to the organisation of the NHS in England, including a mix of rules to encourage competition within the health system. In reality, NHS leaders embraced collaboration instead. ${ }^{7} \mathrm{NHS}$ England bypassed the legislation and established sustainability and transformation partnerships and integrated care systems-partnerships of NHS commissioners, providers, and local authorities in 42 areas of England-to lead local service changes. But these partnerships have no formal powers, and rules on competitive tendering can hold back collaboration.

For politicians, the motivation for new NHS legislation may be different. Like NHS England, the health secretary seems convinced of the benefits of collaboration. In a speech in July on the future of healthcare, Matt Hancock said that local "systems will become the foundation stone of the future of the NHS and social care." ${ }^{8}$ But the government may also see legislation as a route to gain tighter control over the day-to-day workings of the NHS-something the 2012 act sought to loosen.

NHS England has become the de facto headquarters for NHS strategy under Simon Stevens, its chief executive. The previous health secretary, Jeremy Hunt, has said he never felt he "lacked a power to give direction" to the NHS under the 2012 act. ${ }^{9}$ But perhaps the incumbent feels less powerful. Reform to bring NHS England under closer political control may also help build a narrative, ahead of any covid-19 public inquiry, that arm's length bodies-not government-are to blame for England's pandemic performance.

\section{Politics over evidence}

NHS reorganisations happen frequently but appear to deliver little benefit. ${ }^{10-13}$ They can also bring additional costs, destabilise services and relationships, and divert resources away from patient care. NHS England has called for targeted legislation rather than wholesale reorganisation of the NHS. ${ }^{1}$ This pragmatic approach makes sense-though even the NHS's more limited proposals risk unintended disruption and may replace one set of workarounds with another. ${ }^{2}$

It is unclear how seriously government is considering more widespread reform, or what the reorganisation of public health agencies may mean for NHS responsibilities. It is much clearer, however, that any moves to bring NHS England under closer ministerial control would be rooted in politics rather than evidence.

The NHS has faced the most difficult year in its history and is heading into what is likely to be its bleakest winter. The challenges facing the NHS when it emerges from the pandemic are enormous. The backlog of unmet healthcare need is substantial. ${ }^{14}$ NHS staffing shortages stand at over 100 000-and could double over the next five years. ${ }^{15}$ Public services also face the challenge of reducing the gaping health inequalities exacerbated by covid-19. Major structural reorganisation of the NHS would not be the answer to these problems-and would probably make them harder to fix.

If the government is interested in structural reform, a better place to look would be adult social care in England. The pandemic has taken a grim toll on social care users and staff, and central government action to support the sector has been too slow and inadequate. ${ }^{16}$ Covid-19 has exposed longstanding political neglect-including historical underfunding, chronic workforce problems, and high levels of unmet need. Fundamental reform is needed to transform the current threadbare safety net into a system that 


\section{offers much more generous and effective state protection for} vulnerable people and their carers.

Competing interests: I have read and understood BMJ policy on declaration of interests and have no relevant interests to declare.

Provenance and peer review: Commissioned; not externally peer reviewed.

1 NHS England, NHS Improvement. The NHS's recommendations to government and parliament for an NHS Bill. 2019. https://www.england.nhs.uk/wp-content/uploads/2019/09/BM1917-NHSrecommendations-Government-Parliament-for-an-NHS-Bill.pdf

2 Alderwick H, Gardner T, Thorlby R, Dixon J. Proposed changes to NHS legislation. BMJ 2019;365:11670. doi: 10.1136/bmj.11670 pmid: 30975665

3 Campbell D. Boris Johnson plans radical shake-up of NHS in bid to regain more direct control. Guardian 2020 Jul 10. https://www.theguardian.com/society/2020/jul/10/boris-johnson-plansradical-shake-up-of-nhs-in-bid-to-regain-more-direct-control

4 Ham C. Covid-19 exposes NHS fault lines in England. BMJ 2020;371:m3922. doi: 10.1136/bmj.m3922 pmid: 33055106

5 Department of Health and Social Care. The future of public health: the National Institute for Health Protection and other public health functions. 2020. https://www.gov.uk/government/publications/the-future-of-public-health-the-nihp-and-other-public-health-functions/the-future-of-publichealth-the-national-institute-for-health-protection-and-other-public-health-functions

6 Cole DH. Laws, norms, and the institutional analysis and development framework. I Inst Econ 2017;13:829-47doi: 10.1017/S1744137417000030.

7 Alderwick H, Ham C. NHS in England embraces collaboration in tackling biggest crisis in its history. BMJ 2016;352:11022. doi: 10.1136/bmj.i1022 pmid: 26902256

8 Hancock M. The future of healthcare [speech], 30 July 2020. https://www.gov.uk/government/speeches/the-future-of-healthcare

9 Timmins N. Glaziers and window breakers: former health secretaries in their own words. Health Foundation, 2020doi: 10.37829/HF-2020-C03.

10 Le Grand J, Mays N, Mulligan J, eds. Learning from the NHS internal market. King's Fund, 1998.

11 Smith J, Mays N, Dixon J, etal. A review of the effectiveness of primary care-led commissioning and its place in the NHS. Health Foundation, 2004

12 Mays N, Dixon A, Lorelei J, eds. Understanding New Labour's market reforms of the English NHS. King's Fund, 2011.

13 Ham C, Baird B, Gregory S, Jabbal J, Alderwick H. The NHS under the coalition government. Part one: NHS reform. King's Fund, 2015.

14 Gardner T, Fraser C, Peytrignet S. Elective care in England: assessing the impact of COVID-19 and where next. Health Foundation. 2020. https://www.health.org.uk/publications/longreads/elective-care-in-england-assessing-the-impact-of-covid-19-and-where-next

15 Shembavnekar N. Going into COVID-19, the health and social care workforce faced concerning shortages. Health Foundation, 2020. https://www.health.org.uk/news-and-comment/charts-andinfographics/going-into-covid-19-the-health-and-social-care-workforce-faced-concerning-shortages

16 Dunn P, Allen L, Humphries R, Alderwick H. Adult social care and COVID-19: assessing the policy response in England so far. Health Foundation, 2020doi: 10.37829/HF-2020-P06.

This article is made freely available for use in accordance with BMJ's website terms and conditions for the duration of the covid-19 pandemic or until otherwise determined by BMJ. You may use, download and print the article for any lawful, non-commercial purpose (including text and data mining) provided that all copyright notices and trade marks are retained. 